\title{
GROWTH OF WEEDS IN CEREAL POPULATIONS
}

\author{
LEILA-RIITta ERviö \\ Institute of Plant Husbandry, University of Helsinki
}

Received August 21, 1971

\begin{abstract}
The weeds in this study consisted mainly of Chenopodium album, Stellaria media, Viola arvensis, Polygonum convolvulus, $P$. aviculare and $P$. lapathifolium. Increasing cereal seed rates reduced the numbers, individual weights and total yields of the most abundant species, Chenopodium album. The decreases in plant weight and total yield of the weeds were very steep when the cereal seed rate was raised from 25 to $200 \mathrm{~kg} / \mathrm{ha}$. Increases in the seeding rate reduced the total yields of weeds rather than their numbers. The effect of the cereal on weeds became apparent as soon as heading of the cereal was complete and was further enhanced by prolonged competition. Added nitrogen raised the weed yields at cereal seed rates of $25-100 \mathrm{~kg} / \mathrm{ha}$ but reduced them at higher seed rates. Nitrogen also raised the yield and individual plant weight of $C$. album. Cereal seed rate did not affect the nitrogen, phosphorus, potassium, calcium and magnesium contents of the weeds grown among the crop. Due to larger total weed yields, however, the amounts of these nutrients in the weeds were higher in sparse than in dense cereal populations.
\end{abstract}

The average number of weeds on those Finnish spring cereal fields where no weed control has taken place are 550 plants $/ \mathrm{m}^{2}$ (Mukula et al. 1969). A spring cereal population of normal density consists of an approximately equal number of cereal plants, and it is important in the interest of plant production to study the competitive abilities of weeds under different environmental conditions. Winifred and Brenchley (1917), RAdemacher (1940, 1950), Granström (1959, 1962) and Suomela and PaAtela (1962), among others, have made such studies. The effects of cereal seed rate and nitrogen fertilization on the growth of weeds among cereals were studied at the Institute of Plant Husbandry of the University of Helsinki, Viikki, in the years 1966-68.

\section{Material and methods}

Weed growth was studied in cereal seed rate trials where no weed control measures had been taken. The cereals grown were oats var. Sisu and spring wheat var. Svenno. A split-plot design was used with three replicates in 1966, and four in 1967-68. Ample basic dressing was applied to the soil which was fine sand. In 1966 the trials comprised two levels of nitrogen fertilization, 0 and $100 \mathrm{~kg} / \mathrm{ha} \mathrm{N}$. Seeding rates for the oats and wheat were $25,50,100,200,400,800$, and $1600 \mathrm{~kg} / \mathrm{ha}$. These produced populations of the following average densities at the seedling stage: $80,140,213,414,760,1514$, and 
2708 plants $/ \mathrm{m}^{2}$. The trial plots were irrigated by overhead spray to secure uniform emergence of seedlings.

Weed counts by species were made within $0.10 \mathrm{~m}^{2}$ sample areas marked on the plots twice during the growing season, in 1966 a) at the 3-leaf stage of the cereals and b) when heading of the cereals was complete, in 1967-68 a) at the 3-leaf stage and b) when the cereals were ripe. From each trial plot the weeds from $2 \times 0.10 \mathrm{~m}^{2}$ sample areas were collected when the cereals were in ear and for a second time shortly before cereal harvest. Sample dry weights were determined and the plants in each sample counted; from these figures average individual plant weights were calculated. Individuals of Chenopodium album were counted separately and their dry matter yields determined. Nitrogen, phosphorus, potassium, calcium, and magnesium contents of the weed yields were determined on the cereal plots sown with $25,100,400$, and $1600 \mathrm{~kg} / \mathrm{ha}$. Total nitrogen was determined by the Kjeldahl method and phosphorus colorimetrically by the molybdenum blue method (KaILA 1955). The other nutrient elements were determined by atomicabsorption spectrophotometer.

\section{Weather conditions in the growing seasons $1966-68$}

Table 1 presents the average temperatures and amounts of precipitation for the summer months of $1966-68$. Summer 1966 was generally favourable to plant development despite slightly less than normal rainfall throughout the season. The rainiest month was July. June 1967 was cooler than normal, especially during the early part of the month, which hampered plant growth to some extent. Conditions became more favourable during the latter half of the month, and August-September were warmer than normal. Rainfall was lower than normal in June and July but higher than normal during the latter part of the summer; August was the wettest month. June 1968 was slightly warmer than normal but July was generally cloudy and rather cool. August again was dry and warmer than normal by about $1^{\circ}$ C. Precipitation was abundant in May, but the early part of June was very dry. July with less than average precipitation was nevertheless the rainiest of the summer months.

Table 1. Variation from the mean monthly values of temperatures and rainfall during the growing seasons in Viikki, $1966-68$.

\begin{tabular}{|c|c|c|c|c|c|c|c|c|}
\hline \multirow[t]{3}{*}{ Month } & \multicolumn{4}{|c|}{ Average temperature $\mathrm{C}^{\circ}$} & \multicolumn{4}{|c|}{ Rainfall mm } \\
\hline & \multicolumn{3}{|c|}{$\begin{array}{l}\text { Variation from the mean } \\
\text { values }\end{array}$} & \multirow{2}{*}{$\begin{array}{c}\text { Mean } \\
1931-60\end{array}$} & \multicolumn{3}{|c|}{$\begin{array}{c}\text { Variation from the mean } \\
\text { values }\end{array}$} & \multirow{2}{*}{$\begin{array}{c}\text { Mean } \\
1931-60\end{array}$} \\
\hline & 1966 & 1967 & 1968 & & 1966 & 1967 & 1968 & \\
\hline May & -0.3 & +0.3 & -1.8 & 9.3 & -25 & +10 & -26 & 41 \\
\hline June & +2.0 & -0.9 & +1.7 & 14.3 & -24 & -28 & -7 & 50 \\
\hline July & +0.4 & -0.9 & -2.1 & 17.0 & -5 & -36 & -16 & 73 \\
\hline August & -0.9 & +0.3 & +0.9 & 15.4 & -31 & +38 & -18 & 71 \\
\hline September & -1.2 & +2.1 & +0.6 & 10.4 & +1 & +6 & -18 & 67 \\
\hline
\end{tabular}


Results

$\mathrm{Nu} \mathrm{m}$ b e r of $\mathrm{w}$ e e d s. The numbers of weeds varied considerably in the different years. The most abundant species, making up an average of $89 \%$ of the sample material, were Chenopodium album, Stellaria media, Viola arvensis, Polygonum convolvulus, P. aviculare, and P. lapathifolium.

Increasing seed rates of the cereals generally caused reductions in the numbers of weeds (Fig. 1, Table 2). The effect became more evident as the growing season progressed. In 1967 the numbers of weeds declined consistently towards the autumn, whereas in 1968 the decrease was obvious, at higher cereal seed rates only (Table 2). The effect of nitrogen fertilization on the number of weeds was not yet significant in June 1966, but in July there were significantly less weeds on the fertilized plots $\left(\mathrm{N}_{100}\right)$ than on the non-fertilized one $\left(\mathrm{N}_{0}\right)$.

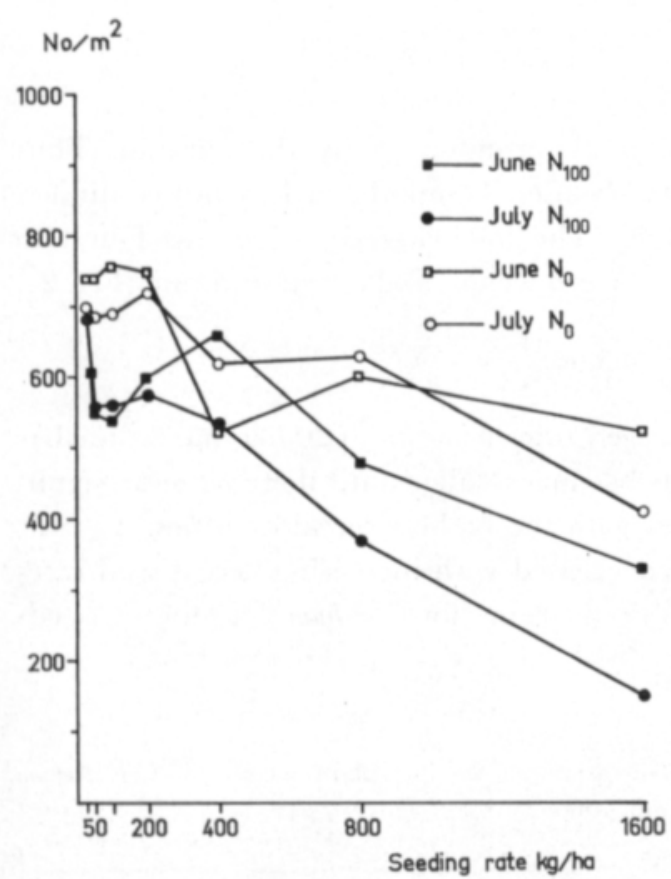

Fig. 1. Effect of cereal seed rate and nitrogen fertilization on the number of weeds in 1966.

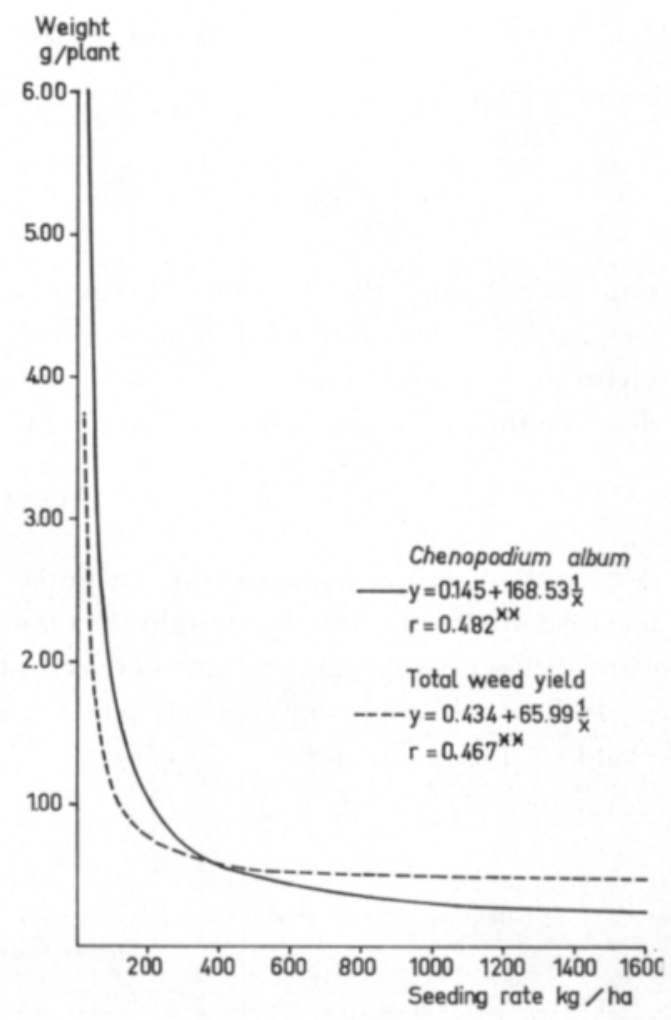

Fig. 2. Effect of cereal seed rate on the per-plant weight of $C$. album and of the total weed yield in average $1967-68$.

Individual plant weight. Average individual weights of weeds were determined in the years 1967-68. Increasing the cereal seed rate reduced the individual weed weights significantly (Fig. 2). As soon as heading of the cereal was complete, weed plants among the dense populations appeared smaller in size than those among the sparse 
Table 2. Effect of cereal seed rate on the number of weeds in $1967-68$. $1=$ cereal at 3 -leaf stage, $2=$ cereal ripe.

\begin{tabular}{|c|c|c|c|c|}
\hline \multirow{3}{*}{ Seed rate $\mathrm{kg} / \mathrm{ha}$} & \multicolumn{4}{|c|}{ Number of weeds per $\mathrm{m}^{2}$} \\
\hline & \multicolumn{2}{|c|}{1967} & \multicolumn{2}{|c|}{1968} \\
\hline & 1 & 2 & 1 & 2 \\
\hline 25 & 189 & 136 & 54 & 64 \\
\hline 50 & 156 & 134 & 52 & 66 \\
\hline 100 & 141 & 129 & 49 & 62 \\
\hline 200 & 107 & 96 & 58 & 55 \\
\hline 400 & 103 & 81 & 63 & 30 \\
\hline 800 & 114 & 70 & 20 & 19 \\
\hline 1600 & 58 & 43 & 24 & 10 \\
\hline LSD & $15^{*}, 20^{* *}$, & plants $/ \mathrm{m}^{2}$ & $12 *, 16 * *$, & plants $/ \mathrm{m}^{2}$ \\
\hline
\end{tabular}

populations, and the difference became still more pronounced by the autumn. Thus weed growth was suppressed in dense cereal stands after the middle of July but continued vigorous in sparse stands with small seed rates. The following equation was found to describe the interrelationship between individual weed weight and cereal seed rate (Fig. 2):

$$
y=0.434+65.99 \frac{1}{x}
$$

A very sharp fall in plant weight was noted at seed rates from 25 to $200 \mathrm{~kg} / \mathrm{ha}$. At further increases of seeding rate the weight decrements became smaller until there were no significant differences in plant weight between plots with the highest cereal densities.

Individual weights of $C$. album plants also decreased with increasing cereal seed rates (Table 3, Fig. 2). In 1967-68 the decline was even steeper for C. album than for all weeds

Table 3. Effect of cereal seed rate and nitrogen fertilization on the per-plant weight of Chenopodium album, autumn 1966.

\begin{tabular}{rrr}
\hline & \multicolumn{2}{c}{ Relative weights } \\
\cline { 3 - 4 } 25 & $\mathrm{~N}_{\mathbf{0}}$ & $\mathrm{N}_{\mathbf{1 0 0}}$ \\
\hline 50 & 100 & 378 \\
100 & 133 & 272 \\
200 & 101 & 172 \\
400 & 75 & 66 \\
800 & 6 & 49 \\
1600 & 5 & -
\end{tabular}


(Fig. 2). In 1966 the greatest weight reductions occurred on the plots with added nitrogen, for the effect of fertilization on plant size was most prominent at low levels of cereal seed rate (Table 3). By September most $C$. album plants in the densest cereal stands had died, and the surviving individuals were smaller in size than those among the sparse stands.

Nitrogen fertilization increased the weight of $C$. album. Average plant weight in the autumn was $0.32 \mathrm{~g}$ on the $\mathrm{N}_{0}$ plots and $0.86 \mathrm{~g}$ on the $\mathrm{N}_{100}$ plots.

$\mathrm{Y}$ i e lds. The largest autumn weed yield from the plots with low seeding rates of cereal was $5330 \mathrm{~kg} / \mathrm{ha}$. Increasing the seed rate caused a rise in the grain yield and a very distinctive fall in the weed yield in all three years. Figures 3 and 4 illustrate the sharp decline in weed yield caused by cereal seed rate increments from 25 to 200 and $400 \mathrm{~kg} / \mathrm{ha}$. In general the yield decline appeared steeper in the autumn than in the summer, for in the course of the growing season weed yields increased more in the sparse than in the dense cereals. On many occasions weed crops among dense cereal populations actually decreased towards the end of the growing season as a result of the death of some weed plants (cf. Table 2).

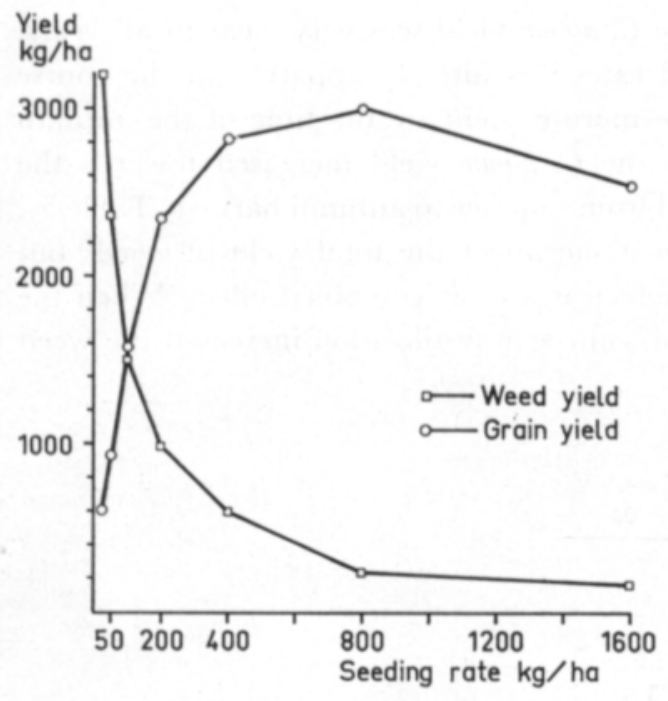

Fig. 3. Effect of cereal seed rate and nitrogen fertilization on the grain yield and the weed yield in the autumn 1966.

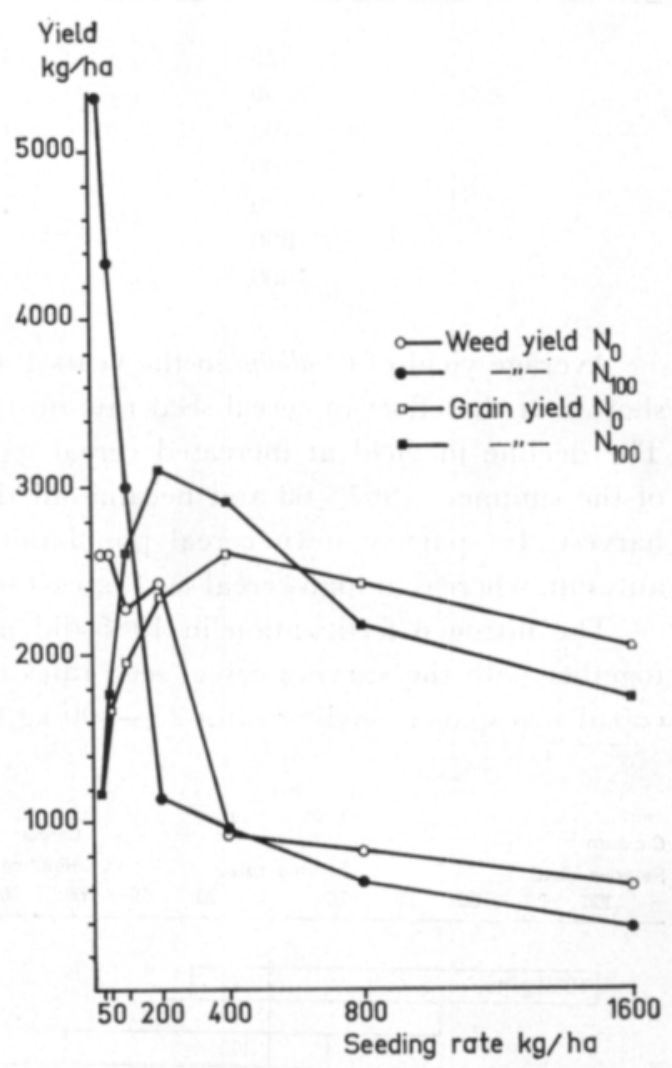

Fig. 4. Effect of cereal seed rate on the grain yield and the weed yield in the autumn $1967-68$. 
Table 4. Effect of cereal seed rate on the yield of C. album, autumn 1966.

\begin{tabular}{|c|c|c|c|}
\hline \multirow{2}{*}{ Seed rate $\mathrm{kg} / \mathrm{ha}$} & \multicolumn{3}{|c|}{ Relative yields } \\
\hline & $\mathrm{N}_{0}$ & $\mathrm{~N}_{100}$ & \\
\hline 25 & $634 \mathrm{~kg} / \mathrm{ha}=100$ & 448 & \\
\hline 50 & 34 & 251 & \\
\hline 100 & 9 & 124 & s. \\
\hline 200 & 7 & 41 & \\
\hline 400 & 1 & 15 & \\
\hline 800 & 0 & 0 & \\
\hline 1600 & 0 & 0 & \\
\hline
\end{tabular}

Table 5. Effect of cereal seed rate on the average yield of $C$. album in $1967-68$.

1 = cereal headed, 2 = cereal ripe.

\begin{tabular}{ccc}
\hline \multirow{2}{*}{ Seed rate kg/ha } & \multicolumn{2}{c}{ Dry matter yield kg/ha } \\
\cline { 2 - 3 } & 1 & 2 \\
\hline & & \\
50 & 430 & 1910 \\
100 & 450 & 1000 \\
200 & 190 & 340 \\
400 & 130 & 180 \\
800 & 130 & 60 \\
1600 & 60 & 10 \\
& 40 & 5
\end{tabular}

Average yield of C. album in the years $1967-68$ was $500 \mathrm{~kg} / \mathrm{ha}$. Table 4 and Figure 5 show that the effect of cereal seed rate on the $C$. album yield was very clear in all years. The decline in yield at increased cereal seed rates was already apparent in the course of the summers 1967 - 68 and became all the more evident by the time of the autumn harvest. In sparsely sown cereal populations the $C$. album yield increased towards the autumn, whereas at high cereal seed rates it fell from summer to autumn harvest (Table 5).

The nitrogen fertilization in 1966 did not alone affect the total yield of weeds but together with the varying cereal seed rates there was a clear combined effect. When the cereal was sparse (seeding rates $25-100 \mathrm{~kg} / \mathrm{ha}$ ), nitrogen fertilization increased the weed

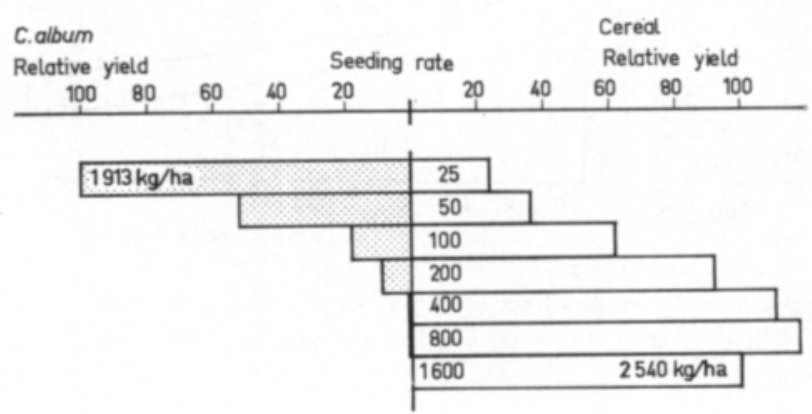

Fig. 5. Effect of cereal seed rate on the relative yields of cereal grain and of $C$. album in the autumn $1967-68$. 
crop, whereas in dense populations added nitrogen helped the cereal plants in controlling the growth of weeds quite effectively (Fig. 3). The yield of weeds among the densest cereal was at the time of cereal heading $1.6 \%$ and in the autumn $6.8 \%$ of that of the weeds grown among the sparsest cereal.

Yields of $C$. album were significantly increased by nitrogen (Table 4). The effect of $\mathrm{N}$ was particularly strong in sparse cereal populations, where $C$. album produced yields many times bigger than the control.

Nutrient element contents of the weeds. In 1966-68 the weeds contained the following average amounts of diflerent nutrient elements:

Cereal headed

$(16 / 7)$

Nitrogen
Phosphorus
Potassium
Calcium
Magnesium

$3.05 \%$

0.41 "

4.60 "

1.66 "

0.52 "
Cereal ripe

$1.53 \%$

0.26 "

2.28 "

0.79 "

0.37 "

$\mathrm{N}, \mathrm{P}, \mathrm{K}$, and $\mathrm{Ca}$ contents of the weeds were significantly higher in July than in the autumn. In 1966 nitrogen fertilization raised the nitrogen content of the weeds $\left(\mathrm{N}_{0} 1.30 \%\right.$, $\mathrm{N}_{100} 1.66 \%$ ). Variations in cereal seed rate did not affect the nutrient contents of the weeds; this indicates that the relative uptake of nutrients by the weeds remained unaffected by increasing competition. Owing to the larger quantity of weeds, however, their total nutrient uptake from the soil was larger among sparse than dense cereal populations (Table 6).

Table 6. Nutrient element contents of the weed yields $\mathrm{kg} / \mathrm{ha}$ in $1966-68$.

\begin{tabular}{|c|c|c|c|c|c|c|}
\hline \multicolumn{2}{|l|}{ Seed rate $\mathrm{kg} / \mathrm{ha}$} & \multirow{2}{*}{$\begin{array}{l}\mathrm{N} \\
46\end{array}$} & \multirow{2}{*}{$\begin{array}{l}P \\
5\end{array}$} & \multirow{2}{*}{$\begin{array}{l}\mathrm{K} \\
71\end{array}$} & \multirow{2}{*}{$\begin{array}{c}\mathrm{Ca} \\
17\end{array}$} & \multirow{2}{*}{$\begin{array}{r}\mathrm{Mg} \\
7\end{array}$} \\
\hline Cereal headed & 25 & & & & & \\
\hline & 100 & 30 & 4 & 46 & 12 & 5 \\
\hline & 400 & 8 & 4 & 21 & 5 & 2 \\
\hline & 1600 & 6 & 1 & 9 & 2 & 1 \\
\hline \multirow[t]{4}{*}{ Cereal ripe } & 25 & 51 & 8 & 87 & 40 & 12 \\
\hline & 100 & 29 & 5 & 55 & 23 & 7 \\
\hline & 400 & 11 & 3 & 19 & 8 & 3 \\
\hline & 1600 & 6 & 1 & 10 & 3 & 1 \\
\hline
\end{tabular}

\section{Discussion}

The number of weeds in cultivated fields is subject to great yearly variation. Observations by MukULA et al. (1969) revealed an average variation in five years from 373 to 641 weed plants $/ \mathrm{m}^{2}$, the mean for the entire period of investigation being 550 plants $/ \mathrm{m}^{2}$. 
At Viikki the number of weeds was particularly high in 1966 as compared with observations made on corresponding dates in the following years (Fig. 2, Table 2). This may be attributed to the generally favourable weather conditions in 1966. The apparent great differences between weed numbers in 1967 and 1968 were not statistically significant owing to wide dispersion of the data.

Variations in the relative proportions of weed species were great in the different years. The bulk of the weeds in all years, however, consisted of Chenopodium album, Stellaria media, Viola arvensis, Polygonum convolvulus, $P$. aviculare, and P. lapathifolium. The three first-named species are counted among the five commonest weed species in Finland (Mukula et al. 1969). According to Mukula and RaAtikainen (1963), individual dry weights of weed plants in 1963 ranged from 0.1 to $1.2 \mathrm{~g}$ with an average of $0.4 \mathrm{~g}$. Somewhat larger weights were recorded at Viikki at the time of cereal harvest (Fig. 2). Increasing densities of cereal crop caused decreases in individual weed weights (Fig. 2). Similar observations were made by Marx and Hagedorn (1961) and Hammerton (1962) who studied the effects on weeds of different growing densities of cabbage and peas.

Lower than normal cereal seed rates resulted in very high total yields of weeds (Figs. 3 and 4). In an earlier Finnish study (Mukula 1963) the average weed yield in spring cereal fields was found to be $1330 \mathrm{~kg} / \mathrm{ha}$ in the years $1961-63$. Previous trials with cereals at Viikki gave an average of $740 \mathrm{~kg} / \mathrm{ha}$ (Suomela and PaAtela 1962). In the present study the average weed yield in 1966 - 68 was $1590 \mathrm{~kg} / \mathrm{ha}$, somewhat higher than the yields reported in literature. The average dry matter yield of C. album at Viikki was $500 \mathrm{~kg} / \mathrm{ha}$, clearly surpassing the average figure for the country which according to Mukula (1963) is $59 \mathrm{~kg} / \mathrm{ha}$.

At a cereal seed rate of $25 \mathrm{~kg} / \mathrm{ha}$ the growth of weeds was luxuriant enough to smother the cereal crop almost totally. Increments in seeding rate produced higher grain yields and reduced the total yields of weeds (Figs. 3 and 4). The effect was on the yields rather than on the numbers of weeds. This is in accordance with earlier studies of competition between weeds and cultivated plants, which likewise have demonstrated that dense stands of cultivated crops are effective in reducing weed yields (WINIFRED and Brenchley 1917, Granström 1962, Nelson and Nylund 1962, Weber and Staniforth 1957, Wiese et al. 1964).

Nitrogen fertilization has been found to increase the numbers and yields of weeds in cereal crops (Suomela and PaAtela 1962). It has been shown, on the other hand, that nitrogen also improves the competitive abilities of cultivated plants thus alleviating the harmful effects of weeds (Koch 1954, Jorge and Staniforth 1961, Granström 1962). The experiments at Viikki in 1966 showed that a sufficiently dense cereal population was capable of arresting the growth of weeds effectively by the aid of nitrogen fertilization. In sparse cereal crops nitrogen caused increases in the dry matter yields of weeds (Fig. 2). This was apparently due to increased plant size since it was found that as a rule the number of weeds declined as a result of nitrogen fertilization (Fig. 11).

According to some reports (Bakke and Pammel 1923, Suomela and PaAtela 1962) oats are more capable of competition with weeds than is wheat. Thurston (1962), on the other hand, considers the genus of the cereal unimportant once the crop is dense enough. At Viikki in 1966 - 68 the results were similar regardless of whether the crop was oats or wheat which were treated together without any discrimination. 


\section{REFERENCES}

Bлкке, A. L. \& Pammel, L. H. 1923. The effect of weeds upon crop production. Proc. Ia. Acad. Sci. 29: $271-279$.

GRANströM, B. 1959. Konkurrensen mellan ogräs och kulturväxten. Växtodling 10: 11-12.

GranströM, B. 1962. Studier över ogräs i vårsådda grödor. Stat. Jordbr.förs. Medd. 130: 1-188.

Hammerton, J. L. 1962. A preliminary study of the competition between kale and three weed species of the genus Polygonum. Weed Res. 2: 274-282.

Jorge, N. H. \& Staniforth, D. W. 1961. Corn-foxtail competition under various production conditions. Agronomy J. 53: 1-5.

KArlA, A. 1955. Studies on the colorimetric determination of phosphorus in soil extracts. Acta Agr. Fenn. 83: 25-47.

Косн, W. 1954. Die Unkrautgemeinschaften der deutschen Dauerdüngungsversuche auf Ackerland. Diss. Hohenheim.

Marx, G. A. \& Hagedorn, D. J. 1961. Plant population and weed growth relations in canning peas. Weeds 9: $494-496$.

MukulA, J. 1963. Kevätviljamaiden rikkaruohojen hehtaarisadoista ja keskipainoista. Koetoim. ja käyt. Erip. 7 p.

Mukula, J. RaAtikainen, T. 1963. Rikkaruohojen painot kevätviljasadossa v. 1963. Koetoim. ja käyt. Erip. 4 p.

Mukula, J., RaAtikainen, M., Lallukka, R. \& RaAtikainen, T. 1969. Composition of weed flora in spring cereals in Finland. Ann. Agric. Fenn. 8: 59-109.

Nelson, D. C. \& Nylund, R. E. 1962. Competition between peas grown for processing weeds. Weeds 10: $224-229$.

RAdemacher, B. 1940. Úber den antagonistischen Einfluss von Roggen und Weizen auf Keimung und Entwicklung mancher Unkräuter. Pfl.bau 17: 131-143.

RADEMACHER, B. 1950. Ưber die Lichtverhältnisse in Kulturpflanzenbeständen, insbesondere im Hinblick auf den Unkrautwuchs (Getreide, Hackfrüchte, Futter-, Ol- und Faserpflanzen). Z. Acker-, Pfl. bau 92: 129.

Suomela, H. \& PaAtel. J. 1962. The influence of irrigation, fertilizing and MCPA on the competition between spring cereals and weeds. Weed Res. 2: 90-99.

Thurston, J. M. 1962. The effect of competition from cereal crops on the germination and growth of Avena fatua L. in a naturally infested field. Weed Res. 2: 192-207.

Weber, C. R. \& Staniforth, D. W. 1957. Competitive relationships in variable weed and soybean stands. Agronomy J. 49: 440-444.

Wiese, A. F., Collier, J. W., Clark, L. E. \& Havelka, U. D. 1964. Effect of weeds and cultural practices on sorghum yields. Weeds 12: 209-211.

Winifred, E. \& Brenchley, W. E. 1917. The effect of weeds upon cereal crops. N. Phytol. 16: 53-76.

\section{SELOSTUS}

\section{RIKKAKASVIEN KASVU VILJAKASVUSTOSSA}

\section{LeILA-RirtTA ERviö}

\section{Helsingin yliopiston kasvinviljelytieteen laitos}

Tutkimuksissa selvitettiin vuosina 1966-68 viljan kylvömäärän ja typpilannoituksen vaikutusta rikkakasvien kasvuun.

Pääosan rikkakasvustosta muodostivat jauhosavikka, pihatähtimö, pelto-orvokki, sekä kierto-, pihaja ukontatar.

Viljan kylvömäärän lisääminen vähensi rikkakasvien lukumäärää, keskimääräistä yksilönpainoa ja 
kokonaissatoa sekä yksittäisistä lajeista jauhosavikan yksilönpainoa ja satoa. Yksilönpaino ja kokonaissato alenivat erittäin jyrkästi kylvömäärän noustessa $25 \mathrm{~kg}$ :sta $200 \mathrm{~kg}$ :aan. Normaali kylvömäärä vähentää siis jo tehokkaasti rikkakasvien satoa. Kylvömäärän lisääminen alensi suhteellisesti enemmän rikkakasvien satoa kuin nïden lukumäärää. Viljakasvuston vaikutus rikkakasveihin näkyi jo viljan ollessa tähkällä ja ilmeni sitä selvempänä, mitä kauemmin kilpailu jatkui.

Typpilannoitus kohotti rikkakasvien satoa viljan kylvömäärän ollessa $25-100 \mathrm{~kg} / \mathrm{ha}$. Sitä tiheämmissä viljakasvustoissa se alensi rikkakasvisatoa. Typpilannoitus kohotti myös jauhosavikan yksilönpainoa ja satoa.

Viljan kylvömäärä ei vaikuttanut rikkakasvien typpi-, fosfori-, kalium-, kalsium- ja magnesiumpitoisuuksiin. Sadon määrästä johtui, että rikkakasvit kuitenkin sisälsivät näitä alkuaineita runsaammin harvassa kuin tiheässä viljakasvustossa. 